\section{PŮL STOLETÍ POČÍTAČŮ V MEDICÍNĚ}

\section{Petr Kocna}

\section{Anotace}

"Cílem vzdělání a moudrosti je, aby člověk viděl před sebou jasnou cestu života, po ní opatrně vykračoval, pamatoval na minulost, znal prítomnost a předvídal budoucnost." (Jan Amos Komenský - O cestě, o minulosti, o budoucnosti, o vzdělání). Před 50ti lety jsme neměli osobní počítače, neexistoval PowerPoint, internet, Google. Můžeme si z postupů a technologií používaných před půl stoletím odnést něco do dnešních dní? Tento materiál není ryze odbornou publikací, ale spíše procházkou po zákoutích vědy a techniky, a je především osobní vzpomínkou na uplynulých 50 let z pohledu lékaře, biochemika a informatika. Stimulací k předkládaným vzpomínkám je i toto prání, které jsem dostal před 5 lety, k šedesátinám "Začnou Ti říkat pamětník právě v době, kdy začneš zapomínat".

\section{Klíčová slova}

osobni počítače, informatika, internet, archivace dat, 50ti letá historie, osobnívzpomínky

\section{1 Úvod}

Jan Amos Komenský (28. březen 1592 - 15. listopad 1670) zemřel před 350 lety, byl posledním biskupem Jednoty bratrské a jedním z největších českých myslitelů, filosofů a spisovatelů. Byl tvưrcem originální, filosoficky ukotvené pedagogické soustavy, z řady jeho děl uvádím Janua linguarum reserata (Brána jazyků otevřená) a Orbis sensualium pictus (Svět v obrazech). Komenský je považován

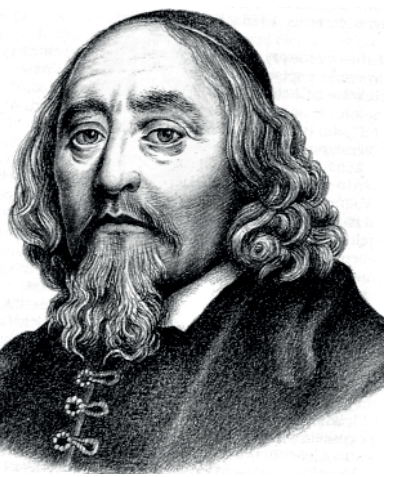
za zakladatele moderní peda- Obrázek 1 - Jan Amos Komenský gogiky a vysloužil si přízvisko (28. březen 1592 - 15. listopad 1670) Učitel národů.

Jak přednášel Jan Amos Komenský? Jak se prezentovalo $v$ éře před PowerPointem? Jak pracovali lékaři, učitelé, vědečtí pracovníci bez počítače a internetu? Můžeme si z postupů používaných před 50 lety odnést něco do dnešních dní? Odpovědí může být citát Jana Amose Komenského "Cílem vzdělání a moudrosti je, aby člověk viděl před sebou jasnou cestu života, po ní opatrně vykračoval, pamatoval na minulost, znal přitomnost a předvídal budoucnost". Celá řada spisovatelů i politiků se vyjadřovala podobně, Alois Jirásek to formulovat takto: "Dnešku plně nerozumí, kdo nezná včerejšku“, Theodor Roosevelt podobně: "Čím více známe svoji minulost, tím lépe jsme připraveni na budoucnost". Před 5 lety, k mým šedesátinám jsem dostal také toto prání: "Začnou Ti říkat pamětník právě $v$ době, kdy začneš zapomínat!". Př́spěvek na letošní MEDSOFT je tedy mojí osobní vzpomínkou na posledních 50 let, dobu neuvěřitelně intenzivní v rozvoji výpočetní techniky.

\section{Publikace, přednášky bez počítače, bez PowerPointu a bez internetu}

V sedmdesátých letech minulého století se přednášelo $s$ diapozitivy, které zhotovovala fotolaboratoř na fakultě. Podklady si lékaři připravovali sami, s pomocí sekretářek, v laboratoři laborantky překreslovaly grafy tuší na pauzák, texty se skládaly z jednotlivých písmen, číslic a znaků kopírovaných ze samolepících transotypů-propisotů. Důležitým zdrojem pro přednášky a publikace je př́istup $k$ odborné literatuře. $V$ době, kdy neexistoval internet, byly zdrojem knihovny a informačním zdrojem tištěný Current Contents, který každý týden vydávala Institute for Scientific Information (ISI).

Instituci založil v roce 1955 Eugene Garfield (16. záŕí 1925 - 26. února 2017) americký vědec, zakladatel bibliometrie a scientometrie [1], Current Contents vydává od roku 1960, a roce 1995 byl jmenován v Karolinu čestným doktorem UK v Praze. Current Contents obsahovaly indexy všech publikovaných článků, citace a především adresy autorů, kterým jsme mohli poštou posílat žádanky o reprint. Návratnost a získání článků podle osobní zkušenosti byla 20 - 30\%.

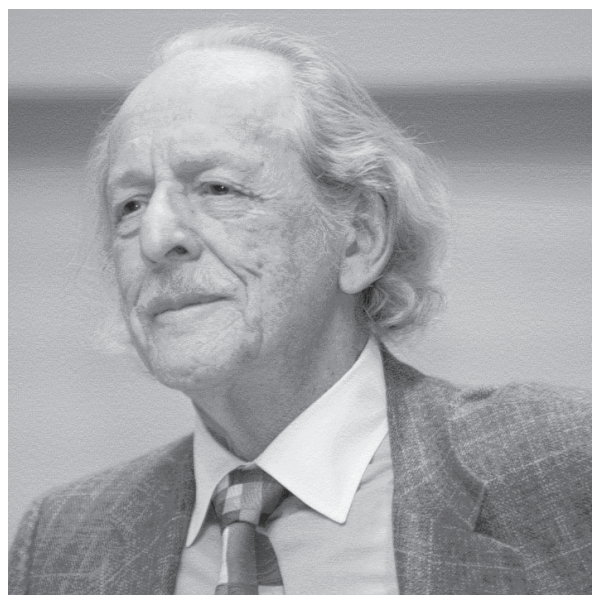

Obrázek 2 - Eugene Garfield (16. září 1925 - 26. února 2017), zakladatel Institute for Scientific Information

Českým projektorem na diapozitivy byl např. Adior II vyráběný od roku 1968 firmou MeOpta (Mechanická Optický výroba) v Přerově. Diaprojektor pro rámečky $5 \times 5 \mathrm{~cm}$ byl automatický, s dálkovým ovládáním. Projekční žárovka měla $300 \mathrm{~W}$ a objektiv Miron 2.8/100. Diapozitivy byly samozřejmě černobílé, pro vyšší kontrast jsme si nakupovali $v$ NDR $v$ metráži ORWO film pro dokumenty DK 5 (citlivost 5 DIN) a v laboratoři jsme si připravovali tvrdou vývojkou s vyšším poměrem metol/hydrochinonu. Profesionální módou byly diapozitivy modro-bílé. Chemickými reakcemi bylo možné ve fotolaboratoři konvertovat stř́bro v emulsi filmu na hexakyanoželeznatan železitý - berlínskou modř.

$$
\begin{aligned}
& \mathrm{Ag}+\left[\mathrm{Fe} \mathrm{el}^{\prime \prime \prime}(\mathrm{CN})_{6}\right]^{3-}>\mathrm{Ag}^{+}+\left[\mathrm{Fe}^{\prime \prime}(\mathrm{CN})_{6}\right]^{4-} \\
& 3\left[\mathrm{Fe}^{\prime \prime}(\mathrm{CN})_{6}\right]^{4-}+4 \mathrm{Fe}^{3+}>\mathrm{Fe}_{4}\left[\mathrm{Fe}^{\prime \prime}(\mathrm{CN})_{6}\right]_{3}
\end{aligned}
$$

Kvalita modro-bílých diapozitivů, transparentnost a jas modré barvy závisely na chemických zkušenostech fotografa, kdy rušící pozadí, nerozpustný bílý síran stříbrný bylo možno rozpustit $\mathrm{HNO}_{3}$, a vytvoření brilantní modře, odstraněním zbytků halogenidu stříbrného, žlutou ustalovací lázní s $\mathrm{Na}_{2} \mathrm{~S}_{2} \mathrm{O}_{3}$.

\section{První stolní počítač}

Americký spisovatel a redaktor "Whole Earth Catalog" Stewart Brand, který se narodil 14. prosince 1938 a žije v Kalifornii, napsal již v roce 1972 "At' již jsou lidé připraveni či nikoliv, počítače přicházejí. Je to dobrá zpráva, možná nejlepší od dob psychedelických drog." Do naší laboratoře jsme dostali první stolní počítač - stolní kalkulátor Hewlett Packard HP 9815A [2] v roce 1976. Cena byla v tomto roce 2900 \$. Počítač - třetí generací RPN (reverzní polská notace), založen na mikroprocesoru Motorola MC6800, měl 16ti znakový display, 55mm termální tiskárnu a kazeto-páskovou datovou jednotkou na DC-100 mini-cartridge $s$ kapacitou $94 \mathrm{kB}$. 8 bit I/O interface umožňoval komunikaci s LKB Ultralab 2086 reaction rate-dependent kinetickým analyzátorem. Vše se programovalo v BASICu a program byl limitován na 2008 kroků. Na DC-100 kazetách máme archivované BASIC programy pro řizení analyzátoru, laboratorní výpočty funkčních testů i statistických metod. 


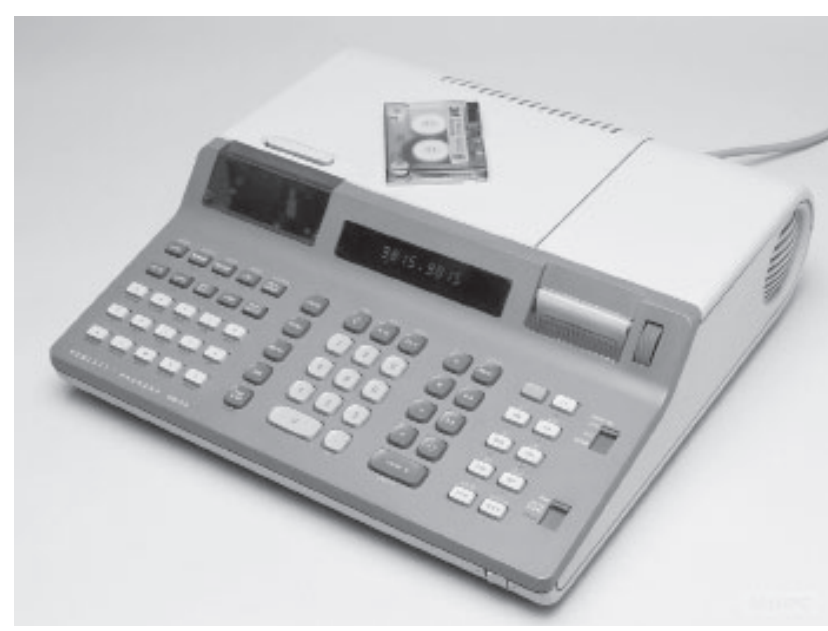

Obrázek 3 - Hewlett Packard HP 9815A programovatelný kalkulátor pro rízení Reaction Rate-Dependent analyzátoru LKB Ultralab 2086

Stolním počítačem již bylo možno označit řídící jednotku HPLC chromatografu Perkin Elmer, který jsme zakoupili v roce 1981. Model 3600 Data Station založený také na mikroprocesoru Motorola MC6800 byl programovatelným CRT terminálem, základní pamět 64 kB byla rozšířená o 320 kB na dvou 5 $1 / 4$ disketách, jedna pro operační systém PETOS (Perkin-Elmer Terminal Operating System), druhá pro ukládání dat. Monitor byl samozřejmě znakový, monochromatický. Termální tiskárna Perkin Elmer 660 byla velmi náročná ekonomicky (termocitlivý papír šíre $20 \mathrm{~cm}$ a fixní $20 \mathrm{~cm}$ mozaiková tisková hlava). Cena 3600 Data Station byla v té době v USA 7.900 \$. Programy jsme tvorili nejen $v$ BASICu, ale naučili jsme se zdrojový assembler a ve spolupráci s techniky Perkin Elmer jsme funkce HPLC chromatografu rozšírili o vlastní HW i SW. Modifikace HPLC systému jsme publikovali v J.Chromatogr.Sci. 1985 [3] a ve třech patentech [4-6].

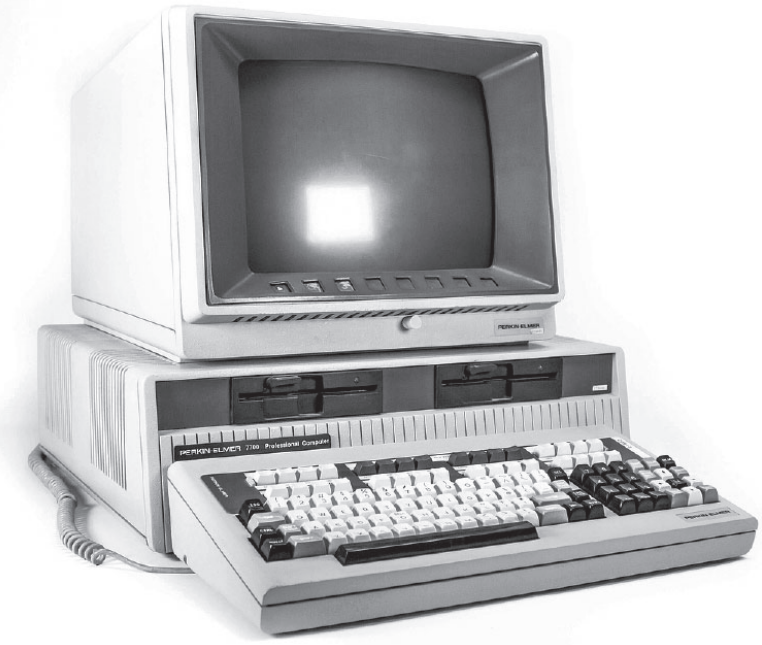

Obrázek 4 - Model 3600 Data Station programovatelný CRT terminál pro HPLC chromatograf Perkin Elmer

\section{Osobní - domácí počítače}

Na počátku osmdesátých let dochází ke zcela zásadní změně v rozvoji stolních a domácích počítačů. 12. srpna 1981 je prezentován firmou IBM model 5150 s 16 bitovým procesorem Intel 8088, RAM 16 - 256 kB, BIOS, PC DOS 1.0. Dovoz IBM kompatibilních počítačủ byl však $v$ této době téměř nemožný a k nám se dostanou koncem osmdesátých let. Kenneth Harry Olsen (1926 - 2011) narozený v Bridgeport (Connecticut, USA), zakladatel a prezident Digital Equipment Corporation (DEC) prohlásil v roce 1977 , tedy pět let před prezentací IBM PC-XT, že
„Není důvodu, proč by chtěl někdo mít počítač doma."

A právě v roce 1982 se začaly, i do česka, dovážet osobní, domácí počítače Commodore 64 . Srdcem počítače je procesor MOS 6510 taktovaný na $1 \mathrm{MHz}$, pamět' RAM je 64 kB/ROM 20 kB. Programování v BASIC V2.0 (stačilo na to $39 \mathrm{kB}$ paměti), grafika - rozlišení 320 × 200, v textovém režimu 40 × 25 znaků, zvukový čip SID byl ve své době považován za hudební zázrak. Pro ukládání programů a dat sloužila jednak kazeto-pásková jednotka nebo disketová mechanika na 5 1⁄4 diskety. Cena počítače Commodore 64 v Tuzexu v březnu 1989 zahrnovala vlastní počítačovou jednotku Commodore 64 II - 9900 Kčs, disketovou mechaniku 1541-II - 10500 Kčs, datasetovou jednotku 1530 (kazeták) - 1500 Kčs a jehličkovou tiskárnu Commodore MPS 1250 - 12240 Kčs. Celková cena 34170 Kčs byla více než trojnásobkem průměrného platu, který v roce 1989 činil 3170 Kčs.

Druhou variantou domácích počítačů byl v roce 1982 Sinclair ZX Spectrum, 8 bitový domácí počítač z Velké Britanie, základem byl CPU Zilog Z80 na 3.5 MHz, ROM 16 kB, grafika 256 x 192 bodů, textový režim 32 x 24 znaků a programování v Sinclair BASIC. Cena ve Velké Britanii v roce 1982 byla 175 £. V česku se začaly vyrábět především pro výuku nelicencované československé klony - Didaktik Gama a Didaktik M. Domácí počítače Commodore 64, Sinclair ZX Spectrum a programy v BASICu byly používány a aplikovány i v medicíně, především v laboratořích. $\checkmark$ roce 1989 jsem zpracoval přehled osmi verzí a rozšírení BASICu pro Commodore 64, publikovaný v časopise Elektronika [7].

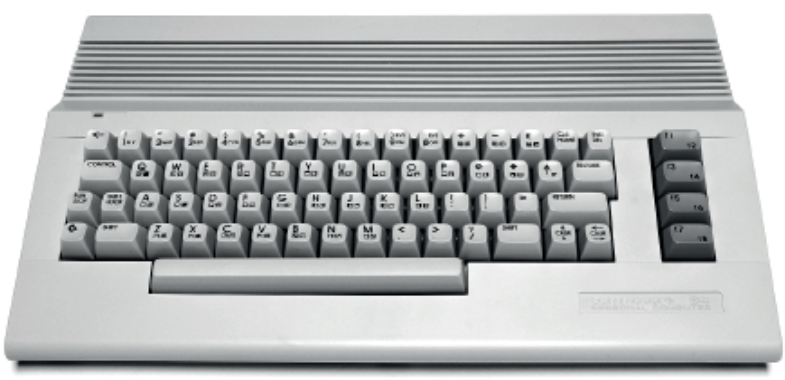

Obrázek 5 - Commodore 64 Personal Computer

\section{Disketové mechaniky}

Magnetická datová média (diskety - floppy disky) vznikly v roce 1971 a původně byly 8" (203,2 mm) s kapacitou 79,2 kB. V dobách osmibitových počítačů byly nejrozšiřrenější disketové mechaniky používající diskety o velikosti 5,25" (133,3 mm) s kapacitou 160 kB - jednostranné diskety nebo 320 kB oboustranné. Diskety 5,25" vymyslel v roce 1976 Alan Field Shugart (1930 - 2006), který v roce 1979 založil firmu Seagate, která vyrobila první 5,25" HDD pro klasické PC. Disketové mechaniky používající diskety 5,25" se dodávaly od roku 1976 prakticky ke všem osobním počítačům (např. Commodore 64), osobním počítačům Apple i IBM kompatibilním. Tato média byla velmi praktická, dala se např́klad posílat poštou (oblíbený a mnohdy
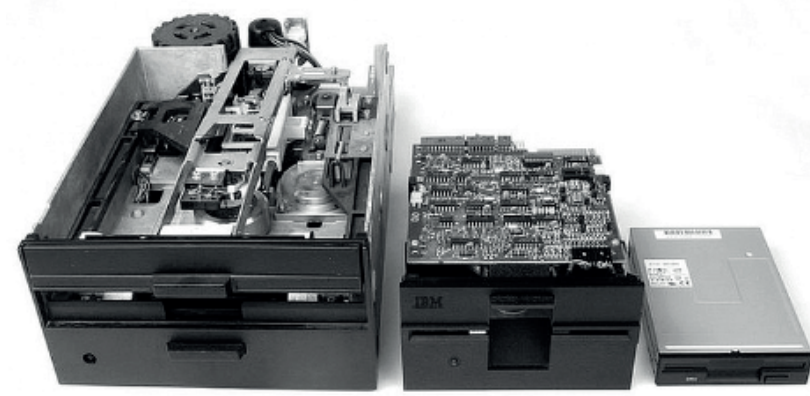

Obrázek 6 - Mechaniky pro floppy diskety - 8" (203,2 mm) 79,2 kB; 5,25" $(133,3 \mathrm{~mm})$ 160/320 kB; 3,5" (88,9 mm) 400/800 kB - 1,44 MB 
také napínavý způsob distribuce softwaru před nástupem BBS a Internetu). V roce 1984 se objevily diskety 3,5 " (88,9 mm) s kapacitou původně 400/800 kB, později 1,44 MB.

Převedeme-li datovou kapacitu dnes běžného flash média se 64 GB na jednostranné diskety se $160 \mathrm{kB}$, pak bychom jich potřebovali 419430 . Pokud bychom diskety poskládali na sebe vzniknul by sloupec vysoký 868.8 metrů, tedy vyšší než nejvyšší mrakodrap světa - Burdž Chalífa v Dubaji ve Spojených arabských emirátech, který má pouze 828 metrů.

\section{IBM kompatibilní osobní počítače}

Malé osobní IBM kompatibilní počítače se ve světě začaly rozšiřovat začátkem 80 . let, ale originály se k nám nedovážely. Prvním, zcela originálním československým mikropočítačem, se stal v roce 1983 PMI-80 (Pieštanský Mikropočítač Intel), vyráběný Teslou Pieštany, který značně připomínal první kroky firmy Sinclair. IBM kompatibilní počítače začal v roce 1987 prodávat Agrokombinát Slušovice [8]. Počítače byly označeny zkratkou TNS (Ten Náš Systém) a model TNS-PC AT 286 byl postaven na procesoru Intel 286, $12 \mathrm{MHz}$, měl $4 \times 256$ kB RAM, EGA grafiku, pevný disk 40 MB, disketu 5,25", MS-DOS 3.0 a jeho cena (pouze pro socialistické organizace) byla 200000 až 300000 Kčs.

Periferní zařízení $\mathrm{k}$ počítačům vznikala také $\mathrm{v}$ českých firmách. Tesla Přelouč nabízela jednojehličkovou tiskárnu BT-100, které se přezdívalo "splašený hřebík". Tisk vznikal přes klasický kopírák a pomocí barevných kopíráků se dalo tisknout barevně, což tehdy všechny šokovalo. Zajímavou variantou byla možnost si jednoduchou tiskárnu poskládat i z Merkuru - "Plotter Merkur Alfi", návod uveřejnil autor Ing. Doval v časopise VTM.

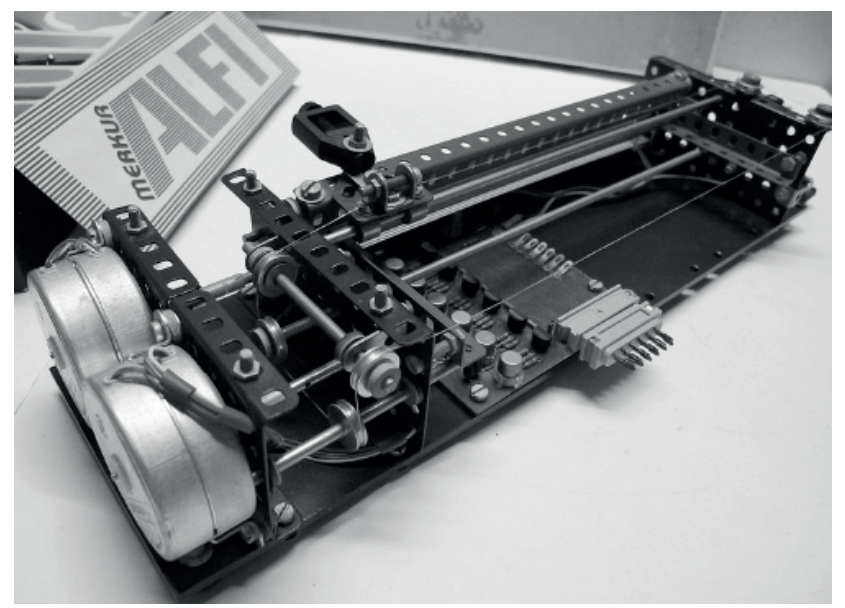

Obrázek 7 - Souřadnicový zapisovač Merkur ALFI plotter

V 80. letech jsme počítače používali pouze v DOS režimu, grafické prostředí Windows nás čekalo až v 90.letech. Grafika v prostředí DOS možná samozřejmě byla. Hewlett Packard vytvořil v roce 1987 nástroje na kreslení vektorové grafiky v HP-GL formátu - Hewlett Packard Graphics Gallery. HP-GL je zkratkou pro grafický jazyk ovládací tiskárny HP a postupně se stal standardem pro téměř všechny plottery. Podklady pro přednášky jsme $v$ 80.letech kreslili na průsvitné fólie A4 formátu, nebo př́mo na tzv. blány, které se rolovaly na cívkách na zpětných projektorech. Grafiku v HP-GL formátu bylo možno překreslit na fólie vektorovým plotterem, který kreslil barevnými lihovými-permanentními fixy. Roland DG nabízel od října 1984 inteligentní plotter X-Y s osmi barevnými pery DG DXY-880, byl založen na mikroprocesoru Zilog Z80, tisknul na A3-A4 papír nebo acetátové folie rychlostí $200 \mathrm{~mm} / \mathrm{s}$, cena plotteru byla 1295 \$.

Přenos grafiky do počítače byl již také možný pomocí skeneru. První skenery byly ruční, uživatel svojí rukou posouval zařízení po předloze a snímač přenášel data do počítače. Kvalita nasnímaného obrazu závisela na tom, jak rovnoměrně a plynule dokázal uživatel posouvat ruku. Jednořádkový skener Geniscan GS-B105 zvládal pouze 256 odstínů šedi a spolupracoval s PC, na kterém byl DOS, GeniScan GS-4500 Logitech, který jsme získali v roce 1990 umožnil skenovat rádek široký $105 \mathrm{~mm}$ ve 400 bodovém režimu. Významým pokrokem byla v této době možnost získávat bibliografické informace Current Contents na disketě (CCOD). Požadavky pro CCOD odpovídaly 80 . létům IBM PC/XT/AT, MS-DOS verze 2.0 a vyšší, 512 kB RAM, 6 MB na hard disku a 3,5" nebo 5,25" floppy mechaniku.

\section{Informační systém GastroBase}

Na Interním oddělení Fakultní polikliniky Fakultní nemocnice (FN2) v Praze byla od června 1990 používána v rutinním provozu lokální počítačová sít a program GastroBase [9]. Počítačová sít' zahrnovala 4 pracovní stanice PC-XT s procesorem 8088, 4/10 MHz, RAM 640 kB, 20 MB hard disk, EGA grafiku, pracující v DOSu. Dodavatelem počítačů LogoStar byla rakouská firma Witrans a objednávku jsme podávali 2. listopadu 1989. File serverem byl počítač PC-AT se 2 MB RAM paměti a 80 MB hard-diskem. Operačním systémem sítě byl Novell Netware 2.15, a komunikace star-topologií ArcNetu.

Program GastroBase byl databázovou aplikací pro sítovou verzi FoxBase a později byl převeden do Btrieve. Originální řešení strukturovaného textu [9-10], kdy text endoskopického (či jiného) nálezu byl zadáván formou krátkých kódů délky 2-4 znaků, které jsou "těsnopisnou zkratkou" části textu byl prokázán jako optimální řešení při vývoji databáze pro gastroenterologické pracoviště prof. Rogose v Lipsku, o kterém bylo referováno na bilaterálním symposiu v lednu 1989 v Bad Berka.

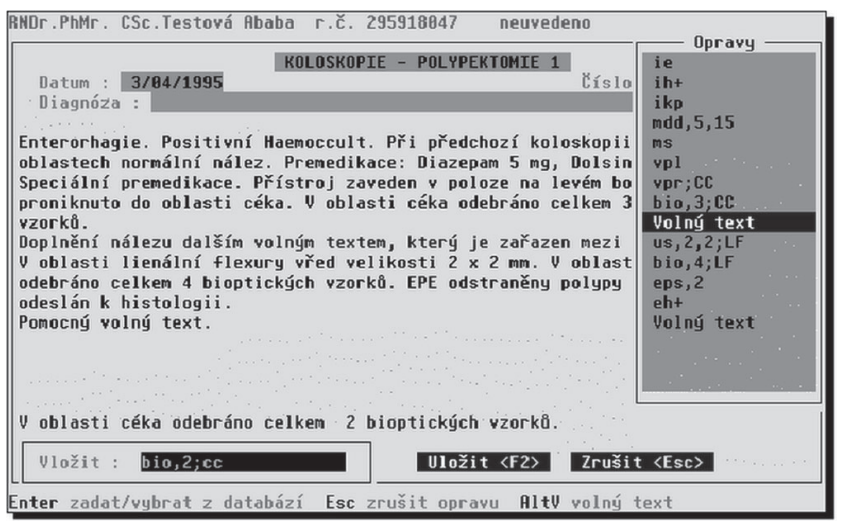

Obrázek 8 - GastroBase - strukturovaný text kolonoskopického vyšetření na interním oddělení Fakultní polikliniky FNII v Praze

Obrazovou dokumentaci jsme do GastroBase začlenili v lednu 1993. On-line digitalizace obrazu byla v informačním systému GastroBase-II umožněna specielním zákaznickým hardwarem firmy ComSyD sro Praha. Originální HW - videokarta VIO - ComSyD je 8bitovou, s video-procesorem M6845 a pamětí 32K x 64. Obrazový interface zahrnuje dva multiplexory a separátory (přepínané RS232 signálem) pro barevný/černobílý monitor, $A / D$ převodník a zesilovače 8bitové datové sběrnice LATCH [11]. Digitalizace obrazu probíhá v reálném čase na 3 průchody pro 16.2 milionů barev. Digitalizované endoskopické, ultrasonografické a RTG obrazy byly archivovány v true-color Targa formátu (soubory .TGA), komprimovány do 256indexového režimu a $v$ informačním systému zobrazovány $v$ grafickém formátu GIF. Strukturovaná data GastroBase umožnila nejen rychlou a jednoznačnou tvorbu textu, ale $v$ dané době optimalizovala i objem ukládaných dat. Zálohu jsme prováděli na interním 3,5" streameru TEAC CT-600H s kapacitou 20MB. Kompletní archiv databáze 60000 vyšetření za 10 let provozu (1990-2000) vyžadoval datový objem pouze $25 \mathrm{MB}$.

V roce 1996 bylo $v$ informační systém Fakultní polikliniky 
VFN Praha 6 lokálních Novell file serverů, 28 pracovních stanic v informačním systému byly moduly pro endoskopie, RTG, US, ambulance, OKB-biochemie a OKH-hematologie. Program GastroBase byl instalován na více než 10 gastroenterologických pracovištích v České Republice. Naše zkušenosti jsme mohli prezentovat na MEDINFO kongresech $v$ Ženevě, Vancouveru a na EPR kongresu v Nashville [12-14].

\section{Grafické uživatelské rozhraní - Windows a PowerPo-} int

Grafické uživatelské rozhraní (GUI) bylo poprvé použito v roce 1973 v počítači Xerox Alto pod názvem WIMP. Popularizaci zajistil nejdříve Apple Macintosh a později Microsoft. Microsoft Windows vyhlásil Bill Gates 10. listopadu 1983 a verze Windows 1.0 byla uvolněna 20. listopadu 1985. Rok 1985 je pro nás podstatný nejen z pohledu informatika. Českoslovenští hokejisté se po finálovém utkání s Kanadou 3. května 1985 radují z titulu mistrů světa a Michail Sergejevič Gorbačov, který 15. října 1990 obdržel Nobelovu cenu za mír, se stává vůdcem Sovětského svazu.

Systém Windows 1.0 nebyl úplným operačním systémem v pravém slova smyslu, ale byl nadstavbou nad 16bitovým systémem MS-DOS. S Windows 1.0 osobní zkušenosti nemám. První systém, který zaznamenal komerční úspěch, byly Windows 3.0 (22. května 1990) a Windows 3.1 (18. března 1992). Jádro těchto systémů obsahovalo částečnou podporu 32bitových ovladačů, které přistupovaly k hardwaru přímo bez využití služeb DOSu a BIOSu.

Naše zkušenosti začínají od speciální verze s názvem Windows 3.1 CE - for Central and Eastern Europe (v zárí 1992) s diakritikou středo a východoevropských jazyků, code page (Windows-1250) a Windows for Workgroups 3.11 (11. srpen 1993) s podporou 32bitového prístupu a sítové komunikace.

Vývoj Microsoft Windows je samozřejmě propojen s nabízeným programovým vybavením. Grafickým nástrojem pro tvorbu elektronických prezentací je jednoznačně PowerPoint, který patří do kancelářského balíku Microsoft Office. PowerPoint vznikl již v roce 1987 a verze PowerPoint 1.0 a 2.0 byly vytvořeny pouze pro Mac, verze 2.0 z roku 1988 byla rozšírena o tvorbu $35 \mathrm{~mm}$ diapozitivů, které stále byly požadovány pro prezentace na konferencích. Verze PowerPoint 3.0 z roku 1992 existuje již pro Windows 3.1 a verze PowerPoint 4.0 z roku 1994 sestává ze součástí Microsoft Office, a s touto verzí jsme začali v naší nemocnici pracovat.

Grafiku prezentací Ize vhodně doplňovat obrázky, kliparty. Nabídka na internetu je dnes téměř neomezená. V devadesátých letech jsme internet neměli a obrázky pro prezentace byly vydávány v publikacích s CD-ROMy. V roce 1994 jsme zakoupili Corel Gallery - 10000 obrázků - požadavek pro instalaci - IBM-kompatibilní 386/486, PS/2, VGA resolution, minimum 4 MB RAM a Windows 3.1. Rozsáhlejší nabídkou byl soubor 16 CD-ROM "Holy Cow 250000 Graphics" vydaný v únoru 1998 Macmillan Digital Publishing.

Prezentace vytvořené v PowerPointu bylo možno překreslit na fólie pro zpětný projektor, ale technologie směřovaly $k$ prímé projekci monitoru. V roce 1994 jsme získali LCD Projection Panel Monitor Proxima Ovation 820 s rozlišením 640 x 480 bodů, 2 mil. barev, který promítal obraz přes zpětný projektor s dostatečně světelným zdrojem. Cena Proxima Ovation LCD Panelu 820 byla 5000 \$. Doplňkem byl interaktivní Cyclops A2030 Pointer, který bylo možno ovládat laserovým ukazovátkem a projekční systém nabízel interaktivní prezentace [15].

Nejčastějším způsobem prezentací však zůstávalo promítání diapozitivů. Online přenos prezentace $z$ PowerPointu na $35 \mathrm{~mm}$ diapozitiv umožňují digitální filmové rekordéry např. firmy Polaroid Corporation. Tuto techniku fotolaboratoř naší fakulty neměla a diapozitivy nám z PowerPoint prezentací od roku 1995 zhotovovali na 2.lékařské fakultě v Motole přístrojem Polaroid Palette 3000 Plus, který spolupracoval s řadou grafických modulů včetně Lotus.

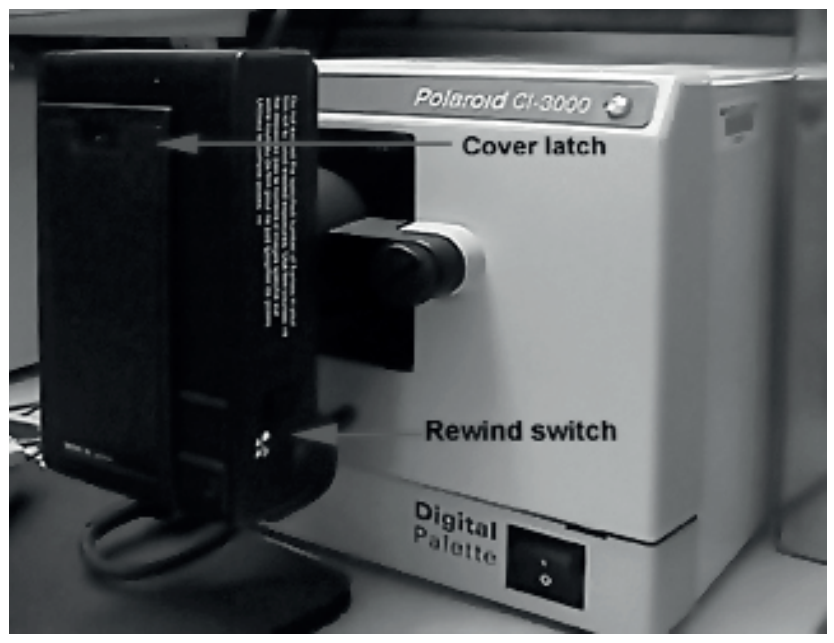

Obrázek 9 - Polaroid Cl-3000 Digital Palette recorder na 35mm kinofilm

Freelance a Harvard Graphics. Na lékařské fakultě Univerzity Palackého v Olomouci publikovali v roce 1998 optimální postup jak diapozitivy fotografovat prímo z obrazovky monitoru počítače [16]. Osvědčila se jim technologie fotografie na barevný diapozitivní film (100 DIN), $70 \mathrm{~mm}$ objektiv pro redukci tvarového zkreslení obrazu na monitoru a clona 16 zajištujúcí delší expozici k eliminaci rádkového rozkladu monitoru.

Prezentace př́mou projekcí počítače dnes zcela běžně umožňují datové projektory typu LCD nebo DLP. Datový projektor jsme získali v roce 1996, typ 3M MP8030 s technologií 3LCD, kdy je bílé světlo rozděleno speciální sestavou dichroického filtru do tři primárních barevných paprsků (červený, zelený a modrý) a každý je nasměrován na svůj vlastní LCD panel.

3M MP8030 Projector umožňoval rozlišení 640 x 480 bodů, VGA režim, obraz v poměru 4:3, metalhalidová lampa měla světelný výkon 500 lumenů a projektor vážil $10.9 \mathrm{~kg}$.

\section{Internet - WorldWideWeb - Google}

Internet z pohledu propojených počítačových sítí vznikl 29. ŕíjna 1969, kdy byla spuštěna první počítačová sít ARPANET ve čtyřech centrech v USA - UCLA (University of California Los Angeles), SCRI (Stanford Central Research Institute), UCSB (University of California Santa Barbara) a University of Utah. Projekt ARPA má historii starší, nebot' ARPA (Advanced Research Projects Agency) vznikla 7. února 1958, jako odpověd USA - Dwight D. Eisenhowera na vypuštění prvního satelitu Sputnik 4. října 1957 v SSSR. Společným cílem internetu je bezproblémová komunikace a výměna dat v celosvětové síti, kdy počítače komunikují pomocí protokolů TCP/IP. V roce 1971 napsal Ray Tomlinson první email a zvolil znak @ k rozdělení jména osoby a označení počítače. Globální statistika ke dni 30. 06. 2019 uvádí, že z celosvětové populace 7716223209 osob používá internet 55.12\%, 4536248808 osob (http://www.internetworldstats.com/stats. htm).

Nejznámější službou poskytovanou $\mathrm{v}$ rámci internetu je WWW - World Wide Web, v doslovném překladu "světově rozsáhlá pavučina". Autorem WWW je Tim Barners-Lee (narozen 8. června 1955), který v roce 1989 v CERNu (Ženeva) představil první návrh WWW, speciální jazyk pro tvorbu dokumentů HyperText Markup Language (HTML) a komunikační protokol - HyperText Transmission Protocol (HTTP). V květnu 1991 byl představen základní model a v červenci 1992 byl již software př́stupný přes internetový prohližeč - klient - WorldWideWeb. V březnu 1993 byl WWW představen v Pitsburghu a v říjnu 1994 
založil Tim Barners-Lee World Wide Web Consortium (W3C), které dohlíží na další vývoj webu.

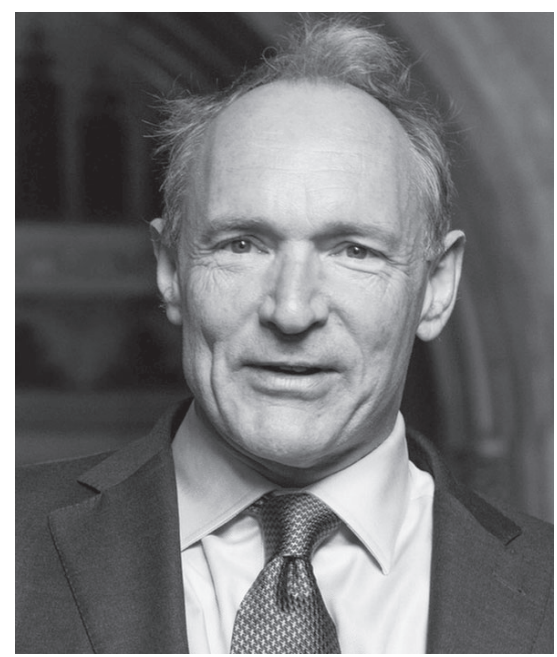

Obrázek 10 - Tim Barners-Lee (narozen 8. června 1955), duchovní otec WorldWideWeb

Český internet vzniká počátkem roku 1990 pomocí komutovaných linek veřejné telefonní sítě. V březnu 1990 se do naší republiky dostává sít FIDO, v květnu sít EUnet a v říjnu EARN (Europian Academic and Research Network) na pevných linkách. Komunikace mezi IBM počítačem 4381 - ČVUT Praha - a národním uzlem EARN v Linci byla 9600 bps. Český projekt dostal jméno FESNET (Federal Educational and Scientific NETwork) a v roce 1992 bylo $\mathrm{F}$ nahrazeno písmenem $\mathrm{C}$ a vznikl CESNET (Czech Educational and Scientific NETwork). Dne 13. 2. 1992 proběhlo slavnostní oficiální připojení naší republiky k internetu a CESNET zprovoznil komunikaci z dejvického ČVUT do výpočetního centra Univerzity Jana Keplera v rakouském Linci. V roce 1994 se Česká republika zapojuje do projektu TEN-34 (Trans-Europian Network Interconnect at $34 \mathrm{Mbit} / \mathrm{s}$ ) a od roku 1995 nabízí CESNET dial-up připojení k internetu [17]. Za 25 let se internet změnil neuvěřitelně. $Z$ původní jedné komutované linky 9.6 kb/s máme v roce 2020 v síti GEANT-CESNET optická vlákna do celého světa s kapacitou $400 \mathrm{~Gb} / \mathrm{s}$. Osobní zkušenosti na 1. lékařské fakultě UK máme od roku 1994, kdy jsem získal emailovu adresu v sítí EARN - kocna@csearn.bitnet.V roce 1996 jsme již mohli používat World Wide Web, Gopher, FTP servery, Telnet a vyhledávač Archie. Pro prezentaci web dokumentů na internetu nabízely v roce 1995 poskytovatelé pro free webhosting pouze $10 \mathrm{MB}$ prostoru. Pro připojení do internetu jsme používali dial-up modemy, externí, interní karty nebo PCMCIA karty do notebooků s rychlostí připojení $56 \mathrm{~kb} / \mathrm{s}$.

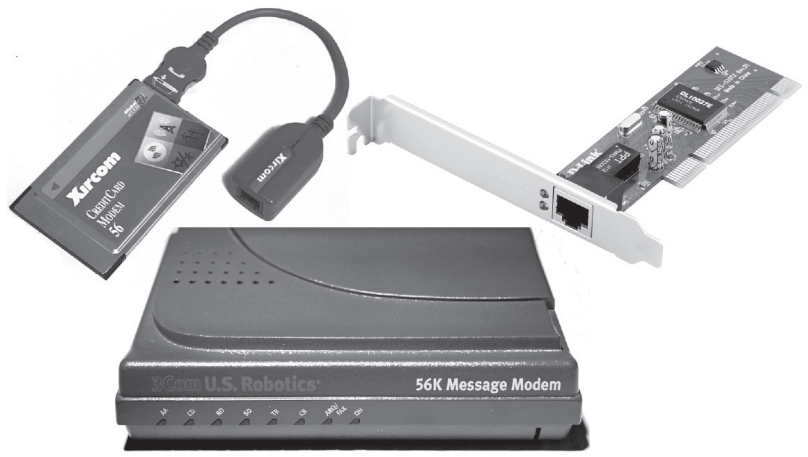

Obrázek 11 - Dial-up konektivita k internetu 56 kb/s externí modem U.S.Robotics, D-Link interní karta a PCMCIA karta Xircom

Vyhledávače na internetu se staly základním nástrojem. V roce 1990 byl prvním vyhledávačem Archie vytvořeny pro prohledávání FTP archivů (File Transfer Protocol), autorským týmem Alan Emtage, Bill Heelan a J. Peter Deutsch z McGill Univerzity v Montrealu (Quebec, Canada). V roce 1998 byl predstaven vyhledávač Google, který pomocí unikátního řadícího algoritmu výrazně změnil pohled na vyhledávání v internetovém obsahu a jeho podíl v celosvětovém přehledu z prosince 2019 je $92.71 \%$. Autorem vyhledávače Google jsou Sergey Brin a Lawrence Page ze Stanford University [18]. Google je navržen jako škálovatelný vyhledávač a primárním cílem je poskytovat vysoce kvalitní výsledky vyhledávání na rychle rostoucím webu a současně se stává kompletní architekturou pro shromažd’ování webových stránek a jejich indexování.

Posledním historickým krokem $\mathrm{v}$ technologiích počítačů a internetu je rozšiření Wi-Fi komunikací, které začalo před 20 lety. Wi-Fi je založeno na principu rozprostřeného spektra, který si již roku 1942 nechali patentovat George Antheil (hudební skladatel) a Hedy Lamarr (herečka rakouského původu). Tato technologie se původně využívala výhradně pro vojenské účely, za války pro rádiově rízená torpéda a na začátku 80. let byla uvolněna i pro civilní využití. $V$ roce 1997 publikoval mezinárodní standardizační institut IEEE specifikaci standardu bezdrátové sítě pracující v pásmu ISM pod označením IEEE 802.11 a otcem Wi-Fi a standardu IEEE 802.11 je Victor Hayes narozený 31. července 1941. Označení Wi-Fi - wireless fidelity (bezdrátová věrnost) je analogií $\mathrm{k} \mathrm{Hi}-\mathrm{Fi}$ - high fidelity (vysoká věrnost). Základním identifikátorem bezdrátové sítě Wi-Fi je SSID (Service Set Identifier).

\section{Zálohování dat, archivace}

Programy napsané v BASICu a data z laboratorních analýz uložené před téměř 50 lety zálohované a archivované máme na magnetických kazetách HP a Scotch DC-100. Nemáme však žádnou možnost jak 50 let stará data přečíst - chybí hardware. Během 50 let jsme data ukládali na TEAC CT-600H kazety s kapacitou 20MB, v 80. letech na QIC (Quarter inch cartridge tape) magnetické pásky zavedené 3M v roce 1972. Začátkem 90. let jsme krátkodobě používali lomega ZIP externí mechaniku a data zálohovali na $100 \mathrm{MB}$ disky, později na zapisovatelné CD-R a DVD-R. Po roce 2000 jsme data archivovali na 640 MB magneto-optické média (MOD) Olympus, Sony a Verbatim. Studie z roku 2006 prezentuje datovou kapacitu, očekávatelnou životnost a stabilitu datových médií používaných pro archivaci [19]. Interní mechanika na MOD média nám koncem roku "zemřela" a náhrada již není. Nemáme tedy již možnost přečíst archivy uložené na MOD. Od roku 2007 archivujeme na externích USB hard discích Western Digital a Toshiba, s kapacitou v dnešní době 1 TB. Jaká je však perspektiva pro dlouhodobou archivaci dat? [20] Projekt CHIMERA "Czech History Information Management and Electronic Records Archiving" pro dlouhodobé ukládání a zpř́istupňování dokumentů $v$ digitální podobě (digitální archiv) byl vypsán již v roce 2004 na základě vládního usnesení č.11/2004. Životnost datových médií, čtecích zařízení nebo software je omezená a ani proces stárnutí informačních technologií se nedá zastavit. $V$ současné době řeší informatika ve zdravotnictví variantu archivace zdravotních dat v cloudu [21].

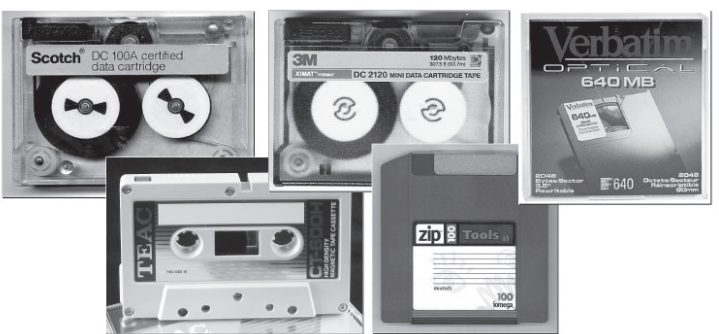

Obrázek 12 - Datová media pro archivaci dat v laboratoři gastroenterologie 1.LF UK a VFN, Scotch DC 100A, TEAC CT-600H, 3M DC 2120, lomega ZIP 100 a Verbatim 640 MOD 
Tabulka 1 - Tabulka dokumentuje datovou kapacitu a očekávatelnou životnost, stabilitu datových médií používaných pro archivaci dat [19]

\begin{tabular}{|l|c|c|}
\hline Archivační medium & Datová kapacita & $\begin{array}{c}\text { Očekávaná } \\
\text { životnost }\end{array}$ \\
\hline Pevný disk - HD & TB & 10 let \\
\hline Datová páska & $400 \mathrm{~GB}$ & 30 let \\
\hline CD-R/RW & $700 \mathrm{MB}$ & $3-100$ let \\
\hline DVD-R/RW & $4.7 / 8.5 \mathrm{~GB}$ & $10-100$ let \\
\hline DVD-RAM & $9.4 \mathrm{~GB}$ & $10-100$ let \\
\hline HD DVD & $15 / 30 \mathrm{~GB}$ & $10-100$ let \\
\hline Blue-Ray & $25 / 50 \mathrm{~GB}$ & $10-100$ let \\
\hline MagnetoOptika & $9.1 \mathrm{~GB}$ & 30 let \\
\hline UDO & $30 \mathrm{~GB}$ & 30 let \\
\hline PDD & $22 \mathrm{~GB}$ & 30 let \\
\hline Holografika & $300 \mathrm{~GB}$ & 30 let \\
\hline
\end{tabular}

\section{Závěr}

Stewart Brand v roce 1972 napsal, že počítače přicházejí, at’ jsou na to lidé připraveni nebo ne. Posledních 20 let máme osobní počítače doma, s prístupem na internet, laptopy, tablety nebo mobily. Tuto prezentaci bych před 50 lety, bez počítače, internetu a Googlu, připravit nemohl. Počítače v medicíně se rovněž staly naprostou samožrejmostí, a při výpadku počítačové sítě v nemocnici se celá řada vyšetření provést nedá, laboratorní automaty bez počítače nespustíme. Na technickém rozvoji v medicíně se jistě podílíme také my - informatici. Považuji proto za vhodné připomenut nyní pana doc. Milana Špálu, CSc, který se narodil 20. listopadu 1930 a zemřel 30. ledna 2018, před 2 lety. Letos by mu bylo 90 let. Na naše konference MEDSOFT jezdil pravidelně a velmi zajímavě přednášel o vědeckém publikování a scientometrii. Byl dlouholetým členem výboru České společnosti zdravotnické informatiky a vědeckých informací České lékařské společnosti J. E. Purkyně.

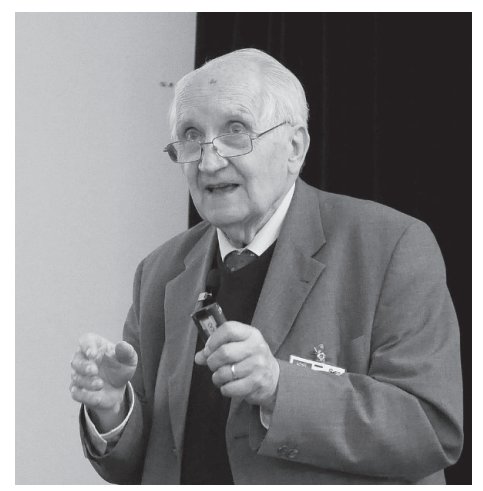

Obrázek 13 - doc. MUDr. Milan Špála, CSc (20. listopadu 1930 - 30. ledna 2018), přednáška na konferenci MEDSOFT 2016

\section{Literatura}

[1.] Garfield, E. - Citation Indexes for Science: A New Dimension in Documentation through Association of Ideas. Science 1955; 122 (3159), $108-111$

[2.] The Museum of HP Calculators HP 9815A/S. http://www.hpmuseum. org/hp9815.htm

[3.] Kocna, P.; Mittermüller, B.J., Modification of a microprocessor-controIled HPLC system (Perkin-Elmer). J.Chrom.Sci., 1985, 23, 3, 132-134

[4.] Kocna, P., Zapojení k automatickému chodu elektricky rízeného ventiIu pro kapalinovou chromatografii., PV 235/85 AO250955, 1988, 1-3

[5.] Kocna, P., Zapojení k ovládání periferních jednotek mikroprocesorem řizeného kapalinového chromatografu., PV 233/85 AO 250451, 1988, 1-3

[6.] Kocna, P., Zapojení k cyklizaci mikroprocesorem rízeného čerpadla pro kapalinovou chromatografii., PV 234/85 AO 249290, 1988, 1-3

[7.] Kocna, P., Commodore C-64 BASIC: rozšířené verse jazyka., Elektroni$k a, 1989,3,2,33-35$

[8.] Kramny T. Jaké byly počítače z JZD Slušovice? https://www.retrobajty. cz/Jake-Byly-Pocitace-Z-Jzd-Slusovice/

[9.] Kocna, P.; Kocna, J.; Frič, P.; Neuwirt, K., Databázové zpracování dat gastroenterologického pracoviště - GastroBase., Katalog MEDSOFT '90, 1990, 20-22

[10.] Kocna, P.; Kocna, J.; Frič, P.: Computer-aided documentation in clinical gastroenterology - GastroBase Proceedings MEDINFO'92 Geneva September 6-10; 1992; 1: 158

[11.] Krása T.: Zpracování a archivace obrazových dat. Diplomová práce ČVUT - Fakulta elektrotechnická, Praha, 1994

[12.] Kocna, P.; Kocna, J.; Frič, P.: Endoscopic results and images using Gastrobase. Computer data processing in clinical gastroenterology. Endoscopy; 1993; 25: 5, 353

[13.] Kocna, P.: The clinical information system GastroBase: Integration of image processing and laboratory communication. MEDINFO'95 Proceedings ed. R.A. Greenes; 1995; 1:, 441

[14.] Kocna, P.: Multimedia Electronic Textbook. The way from clinical information to education. Proceedings TEPR'97, Nashville, May 1997 ; 3: 362-364

[15.] Kocna, P., Elektronická forma přednášky, prezentace - zkušenosti s programem MS Office PowerPoint, Sborník MEDSOFT'96, 1996, 89-91

[16.] Zátura, F.: Moderní možnosti prezentace vědeckých poznatků. Česká urologie 1998;5:36-38

[17.] Krčmařová, G.: 20 let Internetu v České republice. Ikaros 2012, 16/3 https://ikaros.cz/20-let-internetu-v-ceske-republice

[18.] Brin, S., Page L.: The anatomy of a large-scale hypertextual Web search engine? Computer Networks and ISDN Systems. 1998, 30/1-7: 107-117, https://doi.org/10.1016/S0169-7552(98)00110-X

[19.] Marks H.: Strategic Info Management: Long-Term Storage. Network Computing 2006, http://i.cmpnet.com/nc/design06/0914/graphics/ 0914simf1a.gif

[20.] Kocna, P.: Archivace dat - je třicet let mnoho? Sborník MEDSOFT'2007, Ústí nad Labem 20. - 21. brezna 2007, str. 77 - 81.

[21.] Griebel, L., Prokosch, H., Köpcke, F. et al. A scoping review of cloud computing in healthcare. BMC Med Inform Decis Mak.2015, 15:17, https://doi.org/10.1186/s12911-015-0145-7

\section{Kontakt}

MUDr. Petr Kocna CSc.

Ústav lékařské biochemie a laboratorní diagnostiky VFN a 1.LF UK Praha Karlovo náměstí 32, CZ-121-11, Praha 2

web: http://www1.If1.cuni.cz/ kocna/pkweb1.htm email: kocna@lf1.cuni.cz 